Nursing News: Jurnal Ilmiah Keperawatan Vol 5, No 2, Tahun 2021 , hal 63-74

Tersedia online di https://publikasi.unitri.ac.id/index.php/fikes

ISSN 2527-9823(online)

\title{
Efektivitas Penerapan Terapi Musik Mozart (Violin Concerto) Terhadap Nyeri Haid Primer
}

\author{
Yohana Bila Rangga ${ }^{1)}$, Sirli Mardianna Trishinta ${ }^{2)}$, Arie Jefry Ka'arayeno ${ }^{3)}$ \\ 1,2,3) Program Studi Keperawatan Fakultas Ilmu Kesehatan \\ Universitas Tribhuwana Tunggadewi Malang \\ E-mail : yohanabella09@gmail.com \\ E-mail korespondensi: sirli.shinta91@gmail.com
}

\begin{abstract}
Menstrual pain is a symptom that occurs when hormone progesterone in the body is in balanced which can relief with classical music therapy. The purpose of this study was to determine the effect of Mozart music therapy on primary menstrual pain in students of the nursing Program at Tribuwana Tunggadewi University Malang. The research Science design used one-group pre-post test design. Samples are Student of Nursing Science program of UNITRI bortch 2020 which experienced menstrual used or primary menstrual pain amounted 30 people. Data collecting used purposive sampling. Instrument research used by observation level pain or NRS (numerical rating scale). Data analyzed by Marginal Homogeneity Test. The result of the study prove almost half the of student of nursing science program at tribhuwana tunggadewi university malang batch 2020 said the experienced level of primary menstruasi pain are very severe and most of them experienced severe level of paint. The result of marginal homogeneity test obtained $\rangle_{v a l u e}(0,000)<(0,005)$ so that there is on effect of therapy classical music mozart against primary menstrual pain on Student of Nursing Science Program At Tribhuwana Tunggadewi University Malang. Batch 2020. Based on this research, it is hoped that further researchers can ensure other factors that reduce the level of primary menstrual pain.
\end{abstract}

Keyword: Classical Therapy Music; Mozart (Violin Concerto); Primary Menstrual Pain

\begin{abstract}
ABSTRAK
Nyeri haid merupakan suatu gejala yang terjadi ketika hormone progesteron dalam tubuh tidak seimbang yang dapat diredakan dengan terapi musik klasik. Tujuan penelitian ini untuk mengetahui pengaruh terapi musik mozart terhadap nyeri haid primer pada mahasiswi Program Studi Ilmu Keperawatan Universitas Tribhuwana Tunggadewi Malang. Desain penelitian menggunakan One-Group Pre-Post Test Design. Sampel adalah mahasiswi Program Studi Ilmu Keperawatan UNITRI tahun angkatan 2020 yang mengalami nyeri haid primer berjumlah 30 orang, dengan teknik pengumpulan data yang digunakan adalah purposive sampling. Instrumen penelitian menggunakan lembar observasi tingkat nyeri yaitu NRS (Numeric Rating Scale). Analisis data menggunakan Marginal Homogeneity Test. Hasil penelitian membuktikan hampir setengah jumlah mahasiswi program studi Ilmu Keperawatan Universitas Tribhuwana Tunggadewi Malang angkatan tahun 2020 mengatakan mengalami

Cara mengutip: Rangga, Y.B., Trishinta, SM., Ka’arayeno, A.J.(2021). Efektivitas Penerapan Terapi Musik Mozart (Violin Concerto) Terhadap Nyeri Haid Primer. Nursing News: Jurnal Ilmiah Keperawatan. Vol 5, No 2, 2021, hal 63-74. Retrieved from https://publikasi.unitri.ac.id/index.php/fikes/article/view/ 2283
\end{abstract}


tingkat nyeri haid primer yang sangat berat dan sebagian besar mengatakan mengalami tingkat nyeri haid primer yang berat. Hasil Marginal Homogeneity Test didapatkan $\rangle_{v a l u e}=(0,000)<(0,05)$ sehingga ada efektifitas terapi musik mozart terhadap nyeri haid primer pada mahasiswi program studi Ilmu Keperawatan Universitas Tribhuwana Tunggadewi Malang angkatan tahun 2020. Berdasarkan penelitian ini diharapkan peneliti selanjutnya dapat mengukur faktor lain yang menurunkan tingkat nyeri haid primer.

Kata Kunci: Klasik Mozart (Violin Concerto); Nyeri Haid Primer; Terapi Musik

\section{PENDAHULUAN}

Nyeri haid atau dismenore merupakan keluhan rasa nyeri akibat ketidakseimbangan hormone progesteron dalam darah pada sistem reproduksi wanita. Nyeri haid adalah keluhan yang paling sering terjadi pada wanita yang mengalami menstruasi. Nyeri haid yang dirasakan pada saat menstruasi tanpa ada kondisi patologis disebut dengan nyeri haid primer. Karakteristik nyeri haid primer yang dialami wanita seperti rasa tidak nyaman pada area perut bagian bawah yang mungkin juga disertai mual disebabkan meningkatnya kontraksi uterus. Wanita dengan nyeri haid primer mengalami perubahan fisiologis dan psikologis sehingga menjadi mudah marah, cemas dan merasa nyeri sangat kuat sehingga dapat menyebabkan terganggunya aktivitas sehari-hari (Julianti, Hasanah \& Erwin, 2014).

WHO (2019) menyebutkan 80\% wanita di seluruh dunia merasa tidak nyaman atau mengalami nyeri haid saat menstruasi.
Menurut Kemenkes RI mengemukakan bahwa sekitar 40-70\% wanita pada masa reproduksi mengalami dismenore dan sebesar 10\% hingga mengalami gangguan dalam aktivitas sehari-hari. Puncak nyeri haid primer terjadi pada masa remaja akhir (usia 20-an) dimana sekitar 92\% remaja mengalami nyeri haid. Sekitar 70-90\% kasus dismenore dialami pada wanita usia remaja yang dimungkinkan dapat mempengaruhi aktivitas akademis, sosial dan aktivitas. Menurut Dinas Kota Malang (2020) ratarata wanita mengalami nyeri haid dengan tingkatan berbeda-beda yaitu sebanyak $34,2 \%$ termasuk dalam kategori nyeri berat, 36,6\% dalam kategori nyeri sedang dan $29,2 \%$ dalam kategori nyeri ringan. Insiden ini menurun seiring dengan bertambahnya usia dan meningkatnya kelahiran (Sari, Rumini \& Mukarromah, 2017).

Penatalaksanaan nyeri haid biasanya menggunakan farmakologis dan juga diberikan tindakan non farmakologis. 
Tindakan farmakologis yaitu pemberian obat-obatan seperti obat anti nyeri atau obat khusus nyeri haid. Tindakan non farmakologis ini adalah berupa teknik distraksi, stimulasi kulit dan teknik relaksasi. Teknik relaksasi dapat dilakukan seperti teknik relaksasi nafas dalam dan terapi musik. Terapi musik yang digunakan untuk menurunkan nyeri salah satunya yaitu musik klasik karena musik klasik memiliki gelombang yang dibentuk oleh pianna lembut dan cocok untuk didengarkan semua orang (Astuti \& Merdekawati, 2016).

Menurut Amelia (2017) musik dapat mengeluarkan gelombang yang dapat menyeimbangkan dan memperlambat gelombang otak yaitu gelombang beta yang akan mengalihkan perhatian dan kehidupan sehari-hari ataupun suatu perasaan tidak enak. Gelombang alfa yang akan ditimbulkan oleh musik akan memperlambat gelombang otak akan memberikan ketenangan, semakin santai, puas dan mendamaikan perasaan. Pemberian musik ini dimungkinkan dapat efektif dalam penurunan nyeri dismenore. Berdasarkan hasil studi pendahuluan pada tanggal 22 Juni 2020 dengan melakukan wawancara dengan 10 mahasiswi UNITRI Malang yang mengalami haid, didapatkan sebanyak 8 orang mengalami nyeri haid yang sangat hebat sehingga tidak bisa melakukan aktivitas dan sebanyak 2 orang mengalami nyeri tetapi masih bisa ditahan dan melakukan aktivitas kuliah. Dari 10 orang didapatkan keseluruhannya tidak pernah mendengarkan musik mozart untuk menurunkan nyeri haid, namun lebih membeli produk minuman penurun rasa nyeri haid. Hal ini membuktikan bahwa perlu adanya tindakan untuk menurunkan nyeri haid non farmakologis yang mudah salah satunya dengan memberikan terapi musik Mozart. Berdasarkan latar belakang tersebut, maka peneliti tertarik untuk melakukan penelitian dengan judul "efektivitas penerapan terapi musik mozart terhadap nyeri haid primer pada mahasiswi Program Studi Ilmu Keperawatan Universitas Trhibuwana Tunggadewi Malang".

\section{METODE PENELITIAN}

Desain penelitian menggunakan desain penelitian One-Group Pre-Post Test Design (Nursalam, 2013). Populasi dalam penelitian ini adalah seluruh mahasiswi Program Studi Ilmu Keperawatan UNITRI tahun angkatan 2020 yang mengalami nyeri haid selama penelitian sebanyak 42 orang, memenuhi kriteria inklusi, dengan teknik sampling menggunakan simple random sampling 
sehingga didapatkan sampel penelitian sebanyak 30 responden. Adapun kriteria inklusi yang diterapkan yaitu mahasiswi Program Studi Ilmu Keperawatan UNITRI yang mengalami nyeri haid primer, bersedia mendengarkan musik mozart piano concerto selama 30 menit smartphone yang disambung ke headset dan bersedia menjadi responden. Variabel independen yaitu terapi musik mozart, sedangkan variabel dependen yaitu nyeri haid primer. Teknik pengumpulan data menggunakan instrumen berupa lembar observasi. Penelitian dilakukan di Program Studi Ilmu Keperawatan Universitas Tribhuwana Tunggadewi Malang, dimana waktu penelitian dilakukan pada bulan Oktober 2020. Metode analisa data yang digunakan yaitu uji marginal homogeneity.

\section{HASIL}

Tabel 1 menunjukkan seluruh responden yaitu mahasiswi program studi Ilmu Keperawatan Universitas Tribhuwana Tunggadewi Malang tahun angkatan 2020 sebanyak 30 orang $(100 \%)$ berusia $18-21$ tahun dan sebagian besar tidak melakukan tindakan apapun saat mengalami nyeri sebanyak 23 orang $(76,6 \%)$.

Tabel 2 menunjukkan distribusi responden untuk kategori tingkat nyeri haid sebelum diberikan terapi musik mozart bahwa hampir setengah jumlah responden yaitu mahasiswi program studi Ilmu Keperawatan Universitas Tribhuwana Tunggadewi Malang tahun angkatan 2020 mengalami tingkat nyeri haid kategori sangat berat sebanyak 27 orang $(90 \%)$ dan sesudah diberikan terapi musik mozart bahwa hampir setengah jumlah responden yaitu mahasiswi program studi Ilmu Keperawatan Universitas Tribhuwana Tunggadewi Malang Tahun angkatan 2020 mengalami tingkat nyeri haid kategori berat sebanyak 14 orang $(46,6 \%)$, sedangkan mengalami tingkat nyeri haid kategori yang sangat berat sebanyak 6 orang $(20,0 \%)$.

Tabel 1. Distribusi Frekuensi Berdasarkan Karakteristik Responden Program Studi Ilmu Keperawatan Universitas Tribhuwana Tunggadewi Malang

\begin{tabular}{lcc}
\hline \multicolumn{1}{c}{ Kategori } & $\mathrm{f}$ & $(\%)$ \\
\hline $\begin{array}{l}\text { Usia Mahasiswi } \\
\quad 18-21 \text { tahun }\end{array}$ & 30 & 100 \\
$\begin{array}{l}\text { Tindakan Saat Nyeri } \\
\text { Tidak Ada }\end{array}$ & 23 & 76,7 \\
$\quad \begin{array}{l}\text { Minum Air } \\
\text { Hangat }\end{array}$ & 4 & 13,3 \\
$\quad$ Kompres & & \\
$\quad$ Hangat & 1 & 3,3 \\
$\quad$ Menggunakan & & \\
$\quad \begin{array}{l}\text { Minyak Telon } \\
\text { Obat Antibiotik }\end{array}$ & 1 & 3,3 \\
\hline Jumlah & 1 & 3,3 \\
\hline
\end{tabular}


Tabel 2. Data Sebelum dan sesudah Pemberian Terapi Musik Mozart

\begin{tabular}{lcc}
\hline Variabel & $\mathrm{f}$ & $(\%)$ \\
\hline Nyeri haid & & \\
sebelum terapi & & \\
musik Mozart & & \\
$\quad$ Tidak nyeri & - & - \\
$\quad$ Nyeri ringan & - & - \\
$\quad$ Nyeri sedang & - & - \\
$\quad$ Nyeri berat & 3 & 10 \\
$\quad$ Nyeri sangat berat & 27 & 90 \\
\hline Nyeri haid & & \\
sesudah terapi & & \\
music Mozart & & \\
$\quad$ Tidak nyeri & - & - \\
$\quad$ Nyeri ringan & 2 & 6,7 \\
$\quad$ Nyeri sedang & 8 & 26,7 \\
$\quad$ Nyeri berat & 14 & 46,6 \\
$\quad$ Nyeri sangat berat & 6 & 20,0 \\
\hline Total & 30 & 100 \\
\hline
\end{tabular}

Berdasarkan Tabel 3 diperoleh hasil dari Marginal Homogeneity Test diperoleh nilai $J_{\text {value }}$ sebesar $0,000 \quad(<0,05)$ maka dapat disimpulkan terdapat efektifitas atau pengaruh penerapan terapi musik Mozart terhadap nyeri haid primer pada mahasiswi program studi Ilmu Keperawatan Universitas Tribhuwana Tunggadewi Malang tahun angkatan 2020, maka hipotesis penelitian terjawab.

Tabel 3 Hasil Marginal Homogeneity Test Untuk Efektivitas Penerapan Terapi Musik Mozart Terhadap Nyeri Haid Primer

\begin{tabular}{|c|c|c|c|c|c|c|c|c|c|c|}
\hline \multicolumn{2}{|c|}{ Nyeri Haid Primer } & \multicolumn{6}{|c|}{ Sesudah Pemberian Terapi Musik Mozart } & \multicolumn{2}{|c|}{ Total } & \multirow{5}{*}{$\begin{array}{c}\text { Uji } \\
\text { Marginal } \\
\text { Homogen } \\
\text { eity Test } \\
\text { p-value }\end{array}$} \\
\hline & & \multirow{3}{*}{$\begin{array}{l}\text { Nyeri } \\
\text { Ringan }\end{array}$} & \multirow{3}{*}{$\begin{array}{l}\text { Nyeri } \\
\text { Sedang }\end{array}$} & \multirow{3}{*}{\multicolumn{2}{|c|}{$\begin{array}{l}\text { Nyeri } \\
\text { Berat }\end{array}$}} & \multirow{3}{*}{\multicolumn{2}{|c|}{$\begin{array}{c}\text { Nyeri } \\
\text { Sangat } \\
\text { Berat }\end{array}$}} & & & \\
\hline & & & & & & & & & & \\
\hline & & & & & & & & & & \\
\hline & & $\%$ & $\%$ & $\mathrm{~F}$ & $\%$ & $\mathrm{~F}$ & $\%$ & $\mathrm{f}$ & $\%$ & \\
\hline \multirow{5}{*}{$\begin{array}{c}\text { Sebelum } \\
\text { Pemberia } \\
\text { n Terapi } \\
\text { Musik } \\
\text { Mozart }\end{array}$} & Nyeri & 6,7 & 3,3 & 0 & 0,0 & 0 & 0,0 & 3 & 10,0 & \multirow{5}{*}{0,000} \\
\hline & Berat & & & & & & & & & \\
\hline & Nyeri & 0,0 & 23,3 & 14 & 46,7 & 6 & 20,0 & 27 & 90,0 & \\
\hline & Sangat & & & & & & & & & \\
\hline & Berat & & & & & & & & & \\
\hline \multicolumn{2}{|c|}{ Total } & 6,7 & 26,7 & 14 & 46,7 & 6 & 20,0 & 30 & 100,0 & \\
\hline
\end{tabular}

\section{PEMBAHASAN}

Nyeri Haid Primer Sebelum Dilakukan Terapi Musik Mozart (Violin Concerto)

Hasil penelitian menunjukkan bahwa hampir seluruh responden mahasiswi program studi Keperawatan Universitas Tribhuwana Tunggadewi Malang tahun angkatan 2020 memiliki tingkat nyeri haid yang sangat berat sebelum diberikan terapi musik mozart. Hal ini berdasarkan Tabel 2 menunjukkan distribusi responden untuk kategori tingkat nyeri haid sebelum diberikan terapi musik mozart terdapat hampir seluruh responden mengalami 
tingkat nyeri haid kategori sangat berat sebanyak 27 orang $(90 \%)$.

Nyeri haid primer kategori sangat berat disebabkan karena usia yaitu seluruh mahasiswi program studi Keperawatan Universitas Tribhuwana Tunggadewi Malang tahun angkatan 2020 berusia 1821 tahun. Didukung oleh penelitian Manuaba (2013) menjelaskan bahwa faktor resiko terjadinya dismenore primer salah satunya adalah usia dimana hal ini disebabkan sistem reproduksi mengalami perubahan-perubahan dalam proses pematangan sehingga timbul nyeri ketika menstruasi. Dan semakin tua usia perempuan akan mempunyai leher rahim karena seringnya menstruasi, sehingga pada usia tua jarang ditemukan keluhan nyeri haid.

Pada penelitian ini diketahui hampir setengah responden mengalami haid dalam rentang 3-4 hari. Nyeri yang dirasakan oleh wanita pada saat haid merupakan nyeri yang timbul akibat kontraksi disritmik miometrium. Gejala yang muncul mulai dari nyeri ringan sampai berat pada area perut bagian bawah, pantat, dan nyeri disertai berbagai gejala lainnya.
Sebagian besar wanita mengalami derajat nyeri pelvik selama haid yang beragam, namun istilah dismenore dipakai untuk nyeri haid yang cukup berat atau lebih sehingga menyebabkan wanita mencari pertolongan pada dokter atau pengobatan sendiri dengan analgesic pada nyeri haid ringan. Nyeri berat yang dirasakan oleh responden dikarenakan ketidaktahuan dalam penerapan waktu terapi yang tidak tepat dalam mengatasi nyeri yang dirasakan sehingga nyeri yang dirasakan terasa berat.

\section{Nyeri Haid Primer Sesudah Dilakukan Terapi Musik Mozart (Violin Concerto)}

Hasil penelitian menunjukkan bahwa hampir setengah responden mahasiswi program studi Keperawatan Universitas Tribhuwana Tunggadewi Malang tahun angkatan 2020 memiliki tingkat nyeri haid yang berat ketika sesudah diberikan terapi musik mozart. Hal ini berdasarkan Tabel 2 menunjukkan distribusi responden untuk kategori tingkat nyeri haid sesudah diberikan terapi musik mozart terdapat hampir setengah responden mengalami tingkat nyeri haid kategori berat sebanyak 14 orang $(46,6 \%)$.

Mahasiswi yang memiliki tingkat nyeri haid primer kategori berat sesudah diberikan terapi musik mozart. Hal ini 
dipengaruhi penyebab terjadinya dismenore primer yaitu peningkatan kadar prostaglandin yang mengakibatkan peningkatan tonus miometrium dan kontraksi uterus yang berlebihan sehingga menyebabkan nyeri haid (Fritz \& Speroff, 2013).

Penanganan atau tindakan mahasiswi program studi Ilmu Keperawatan Universitas Tribhuwana Tunggadewi Malang tahun angkatan 2020, dalam menangani dismenore belum tepat karena tidak semuanya mengetahui bahwa dismenore bisa diturunkan melalui terapi musik mozart. Hal ini sejalan juga dengan hasil penelitian Firsty (2018) juga bahwa salah satu cara untuk mengurangi nyeri haid adalah dengan mengalihkan perhatian kepada musik sehingga kesadaran merespon nyeri dapat teralihkan bahkan dapat meningkatkan toleransi nyeri seseorang.

Mekanisme teknik distraksi dalam mengatasi nyeri yaitu menghambat stimulus nyeri ketika menerima rangsang sensorik yang menyebabkan terhambatnya impuls nyeri ke otak terhambat dan rasa nyeri berkurang. Apabila stimulus sensori yang diberikan merupakan stimulus yang menyenangkan maka akan merangsang sekresi endorphin. Sehingga stimulus nyeri yang disarankan oleh responden menjadi semakin berkurang dengan teknik distraksi yang menyenangkan tersebut.

Penanganan nyeri juga dapat berpengaruh terhadap tingkat keparahan nyeri yang dirasakan oleh penderita nyeri haid seperti pelaksanaan penanganan nyeri dengan non farmakologi dengan teknik distraksi berupa mendengarkan musik. Terapi musik terbukti menunjukkan efek mengurangi kecemasan dan depresi, menghilangkan nyeri, menurunkan tekanan darah dan menurunkan frekuensi denyut jantung yang dapat juga berdampak pada penurunan nyeri haid. Musik yang dapat digunakan pada penurunan nyeri ini adalah musik lembut dan teratur, seperti instrumental atau musik klasik Mozart (Erfandi, 2009).

Responden yang mengalami nyeri yang ringan dikarenakan produksi prostaglandin tidak secara berlebihan sehingga kemungkinan terjadinya nyeri haid yang dirasakan tidak terlalu berat atau ringan. Hasil penelitian menunjukkan ada hubungan riwayat keluarga dengan kejadian nyeri haid. Sebagian besar responden yang mengalami nyeri haid memiliki riwayat keluarga yang sama, hal ini disebabkan adanya faktor genetik yang dapat mempengaruhi keadaan responden 
sehingga apabila ada keluarga responden yang mengalami nyeri haid cenderung mempengaruhi kondisi psikologis responden. Hal ini didukung hasil penelitian oleh Utami (2013) bahwa ada hubungan yang signifikan antara riwayat keluarga dengan kejadian nyeri haid, sehingga hal ini membuktikan meskipun perbedaan lokasi penelitian, riwayat keluarga tetap memiliki hubungan yang signifikan terhadap kejadian nyeri haid.

Hal lain yang dapat mengurangi nyeri haid menjadi ringan oleh penderita adalah dengan mendengarkan terapi musik dalam waktu yang ideal. Untuk melakukan mendengarkan musik dalam mengurangi nyeri berat adalah waktu selama kurang lebih 15-20 menit hingga satu jam tiap hari, hal ini dikarenakan jangka waktu tersebut akan berdampak pada penurunan nyeri yang dirasakan oleh responden.

\section{Efektivitas Pengaruh Terapi Musik Mozart(Violin Concerto)Terhadap Nyeri Haid Primer}

Hasil penelitian menunjukkan bahwa terdapat efektifitas atau pengaruh penerapan terapi musik Mozart terhadap nyeri haid primer pada mahasiswi program studi Ilmu Keperawatan Universitas Tribhuwana Tunggadewi Malang tahun angkatan 2020. Hal ini berdasarkan Tabel 3 diperoleh hasil tabulasi silang dan uji Marginal Homogeneity Test diperoleh nilai Jvalue sebesar 0,000 (<0,05). Maka dapat disimpulkan hipotesis penelitian terjawab.

Hasil penelitian menunjukkan bahwa sebagian kecil responden mahasiswi program studi Keperawatan Universitas Tribhuwana Tunggadewi Malang tahun angkatan 2020 memiliki tingkat nyeri haid yang sangat berat walau sebelum dan sesudah diberikan terapi musik mozart. Hal ini berdasarkan Tabel 2 menunjukkan distribusi responden untuk kategori tingkat nyeri haid sebelum dan sesudah diberikan terapi musik mozart terdapat sebagian kecil responden mengalami tingkat nyeri haid kategori sangat berat sebanyak 6 orang $(20,0 \%)$.

Didukung oleh penelitian Firsty (2018) mengungkapkan bahwa faktor lain yang dapat menyebabkan nyeri sangat berat adalah waktu, hal ini dikarenakan bahwa waktu yang ideal untuk melakukan mendengarkan musik dalam mengurangi nyeri berat adalah waktu selama kurang lebih 15-20 menit dalam satu kali perlakuan, hal ini dikarenakan jangka waktu tersebut akan berdampak pada penurunan nyeri yang dirasakan oleh responden. 
Haid mengacu pada pengeluaran secara periodik darah dan sel-sel tubuh dari vagina yang berasal dari dinding rahim wanita. Wanita mulai dari usia remaja hingga dewasa normalnya mengalami periode menstruasi atau haid dalam perjalanan hidupnya. Nyeri haid primer adalah rasa nyeri yang terjadi selama masa menstruasi dan selalu berhubungan dengan siklus ovulasi.

Penatalaksanaan nyeri haid primer biasanya menggunakan farmakologis (obat-obatan) seperti obat anti nyeri atau obat khusus nyeri haid, dan juga diberikan tindakan non farmakologis.Tindakan non farmakologis berupa teknik distraksi, stimulasi kulit dan teknik relaksasi. Teknik relaksasi seperti teknik relaksasi nafas dalam dan terapi musik. Terapi musik yang digunakan untuk menurunkan nyeri haid salah satunya yaitu terapi musik mozart. Terapi musik mozart memiliki irama musik yang lembut dan cocok didengar oleh semua kalangan terutama remaja (Julianti, Hasanah \& Erwin, 2014).

Musik Mozart dipilih karena memiliki keunggulan akan kemurnian dan kesederhanaan bunyi-bunyi yang dimunculkannya, irama, melodi, dan frekuensi tinggi pada musik mozart merangsang dan memberi daya pada daerah-daerah kreatif dan motivasi dalam otak. Keunggulan terapi musik yaitu lebih murah dari pada analgesia, prosedur non invasif, tidak melukai pasien, tidak ada efek samping, penerapannya luas, bisa diterapkan pada pasien yang tidak bisa diterapkan terapi secara fisik untuk menurunkan nyeri. Mendengarkan musik mozart membuat tubuh lebih rileks. Musik sebagai salah satu bentuk distraksi, dimana perhatian nyeri dialihkan dengan suara musik atau dapat disebut audio analgesik (penenang). Denyut jantung akan melambat menuju tempo musik yang didengar, semakin lambat denyut jantung maka tubuh semakin rileks. Musik yang masuk ke telinga, kemudian akan menggetarkan gendang telinga dan mengguncang cairan yang ada di telinga bagian dalam dan akan menggetarkan selsel berambut di dalam koklea yang untuk selanjutnya melalui saraf koklearis menuju ke otak dan di otak inilah musik akan mempengaruhi hipofisis untuk melepaskan endorfin.

Endorfin adalah suatu zat analgesik alami yang dimiliki oleh tubuh. Endorfin bekerja dengan cara merangsang area ventrikuler diensefalon atau area grisea periakueduktus yang menghantarkan isyarat nyeri ke nukleus yang terdapat di tengah batang otak, kemudian dari nucleus 
ini lintasan serat tersebut akan turun ke dalam medulla spinlis dan akan berakhir didalam kornu dorsalis dimana tempat saraf sensorik nyeri dari perifer juga berakhir. Akibatnya perangsangan pada area grisea periakueduktus ini yang merupakan sebagai penghantar isyarat nyeri ke nucleus ditengah batang otak, maka akan menghambat dan menekan transmisi impuls nyeri melalui neuron setempat di dalam area tersebut, sehingga nyeri dapat berkurang atau distoleransi (Noviz, 2006, dalam Pradhipta \& Suryani, 2011).

Mendengarkan musik mozart menyebabkan persepsi atau perasaan tenang, meningkatkan hormon serotonin dan endhorphin yang menyebabkan seseorang semakin merasa nyaman, terjadi perbaikan sel dalam uterus sehingga menurunkan kram otot uterus dan respon nyeri haid pun menurun (Djohan, 2016). Mendengarkan musik mozart juga bisa menurunkan frekuensi denyut jantung, mengurangi kecemasan, depresi dan menghilangkan nyeri haid (Heryani \& Utari, 2017). Musik mozart merupakan terapi kesehatan menggunakan musik yang bertujuan untuk meningkatkan atau memperbaiki kondisi fisik, emosi, kognitif, dan sosial bagi individu dari berbagai kalangan usia dengan cara mengalihkan perhatian seseorang pada hal-hal lain sehingga akan lupa pada nyeri yang dialami, dengan demikian akan menurunkan kewaspadaan terhadap nyeri bahkan meningkatkan toleransi terhadap nyeri (Umiyah, 2014). Efektivitas mendengarkan musik mozart dapat memproduksi zat endorphins (substansi sejenis morfin yang disuplai tubuh yang dapat mengurangi rasa sakit/nyeri) yang dapat menghambat transmisi impuls nyeri di sistem saraf pusat, sehingga sensasi nyeri haid dapat berkurang, musik mozart juga bekerja pada sistem limbic yang akan dihantarkan kepada sistem saraf yang mengatur kontraksi otot-otot tubuh, sehingga dapat mengurangi kontraksi otot dan menurunkan rasa nyeri haid (Potter $\&$ Perry, 2011). Hasil penelitian ini juga didukung hasil penelitian oleh Harahap (2018) yang membuktikan bahwa pemberian terapi musik mozart dalam sekali perlakuan berpengaruh terhadap penurunan tingkat nyeri haid dari kategori berat menjadi sedang.

\section{KESIMPULAN}

Hampir setengah jumlah mahasiswi program studi Ilmu Keperawatan Universitas Tribhuwana Tunggadewi Malang angkatan tahun 2020 mengatakan mengalami tingkat nyeri haid primer dengan skala 10 (nyeri sangat berat 
)sebanyak 27 orang; sebagian besar mengalami tingkat nyeri haid primer dengan skala nyeri 7-9(berat)sebanyak 14 orang; dan ada efektifitas terapi musik mozart terhadap nyeri haid primer pada mahasiswi program studi Ilmu Keperawatan Universitas Tribhuwana Tunggadewi Malang angkatan tahun 2020 (\rangle$\left._{\text {value }}=0,000\right)$.

\section{UCAPAN TERIMAKASIH}

Dalam kesempatan ini tak lupa peneliti menyampaikan rasa terima kasih kepada Universitas Tribhuwana Tunggadewi Malang tempat peneliti menimba ilmu, Dr. Ir. Eko Handayanto., M.Sc Selaku Rektor Universitas Tribhuwana Tunggadewi Malang, Drs. Sugeng Rusmiwari, M.Si. Selaku Dekan Fakultas Ilmu Kesehatan, ibu Sirli Mardianna Trishinta, S. Kep., Ns., M. Kep, selaku dosen pembimbing Utama dalam penyusunan karya ilmiah ini, Kedua orang tuaku yang terkasih, Bapak Ngongo Banidan Ibu Leda Milla yang memberikan dukungan material maupun nonmaterial dan juga Marwah dan Clemen yang selalu membantu penelitian ini, sehingga dapat terselesaikan dengan baik.

\section{REFERENSI}

Djohan. (2016). Terapi Musik Teori dan Aplikasi. Yogyakarta: Galang Press.
Dinas Kota Malang. (2020). Masalah Kesehatan Reproduksi Wanita.

Fritz MA \& Speroff L. (2013). Clinical Gynecologic Endocrinology and Infertility, Ed.8. USA, Lippincott Williams \& Wilkins.

Harahap V.A Irmayanti. (2018). Pengaruh Terapi Musik Mozart Terhadap Penurunan Tingkat Nyeri Haid Pada Mahasiswi Tingkat 1 STIKES Prima Jambi. Scientia Journal 7 (1). Universitas Adiwangsa Jambi.

Heryani R., \& Utari M.D. (2017). Efektivitas Pemberian Terapi Musik (Mozart) dan Back Xercise Terhadap Penurunan Nyeri Dysmenorhea Primer. Jurnal Ipteks Terapan 11 (4). STIKes Pekanbaru Medical Center, Pekanbaru Riau.

Julianti, Hasanah O., \& Erwin, (2014). Efektifitas Akupresur Terhadap Dismenore Pada Remaja Putri. JOM PSIK 1 (2)Universitas Riau.

Kemenkes RI. (2019). Manajemen Kebersihan Menstruasi Perlu Dipahami. Jakarta, Kementerian Kesehatan RI Manuaba, I. B. (2013). Penuntun Kepaniteraan Klinike Obstetri dan Ginekologi. Jakarta, EGC.

Natalina, D. (2013). Terapi Musik Klasike Bidang Keperawatan. Jakarta: Mitra Wacana Media. 
Nursalam. (2013). Konsep dan Penerapan

Metodologi Penelitian Ilmu Keperawatan.

Jakarta, Salemba Medika.

Potter \& Perry. (2011). Buku Ajar

Fundamental Keperawatan Proses dan

Praktik. Edisi 4. Jakarta, EGC.

Pradhipta, A.R., \& Suryani. (2011).

Pengaruh Terapi Musik Terbadap Nyeri

Haid (Dismenorea) Pada Remaja Putri

Kelas IIdi SMA N 1 Karangnongko

Klaten. Naskah Publikasi: STIKes

'Aisyiyah Yogyakarta.

Sari, Ika Endah P., Rumini \&

Mukarromah, Siti B. (2017).

Pengaruh Latihan Senam dan Daya

Tahan Tubuh Terbadap Respon Nyeri

Haid(Dysmenorrbea). Journal of

Physical Education and Sports 6 (2).

Universitas Negeri Medan.

Umiyah A. (2014). Pengarub Terapi Musik

Terbadap Perubaban Tingkat Nyeri

Dismenorea.Akademi Kebidanan

Ibrahimy Sukorejo Situbondo.

Oksitosin, Kebidanan 1 (2).

WHO. (2019). Dismenorea. Swiss: World

Health Organization. 